\title{
Long-Term Cocirculation of Two Strains of Pepino Mosaic Virus in Tomato Crops and Its Effect on Population Genetic Variability
}

\author{
C. Alcaide, ${ }^{1}$ M. P. Rabadán, ${ }^{1}$ M. Juárez, ${ }^{2}$ and P. Gómez ${ }^{1, \dagger}$ \\ ${ }^{1}$ Centro de Edafología y Biología Aplicada del Segura (CEBAS-CSIC), Departamento de Biología del Estrés y Patología Vegetal, Campus de \\ Espinardo, Espinardo, CP.30100, Murcia, Spain \\ ${ }^{2}$ Escuela Politécnica Superior de Orihuela, Universidad Miguel Hernández de Elche, Orihuela 03312, Alicante, Spain \\ Accepted for publication 12 September 2019.
}

\begin{abstract}
Mixed viral infections are common in plants, and the evolutionary dynamics of viral populations may differ depending on whether the infection is caused by single or multiple viral strains. However, comparative studies of single and mixed infections using viral populations in comparable agricultural and geographical locations are lacking. Here, we monitored the occurrence of pepino mosaic virus (PepMV) in tomato crops in two major tomato-producing areas in Murcia (southeastern Spain), supporting evidence showing that PepMV diseaseaffected plants had single infections of the Chilean $2(\mathrm{CH} 2)$ strain in one area and the other area exhibited long-term (13 years) coexistence of the $\mathrm{CH} 2$ and European (EU) strains. We hypothesized that circulating strains of PepMV might be modulating the differentiation between them

increased nucleotide variability in the geographical area where both strains cocirculate. Furthermore, the potential virus-virus interaction was studied further by constructing six full-length infectious $\mathrm{CH} 2$ clones from both areas, and assessing their viral fitness in the presence and absence of an EU-type isolate. All $\mathrm{CH} 2$ clones showed decreased fitness in mixed infections and although complete genome sequencing indicated a nucleotide divergence of those $\mathrm{CH} 2$ clones by area, the magnitude of the fitness response was irrespective of the $\mathrm{CH} 2$ origin. Overall, these results suggest that although agroecological cropping practices may be particularly important for explaining the evolutionary dynamics of PepMV in tomato crops, the cocirculation of both strains may have implications on the genetic variability of PepMV populations.
\end{abstract} and shaping the evolutionary dynamics of PepMV populations. Our phylogenetic analysis of $106 \mathrm{CH} 2$ isolates randomly selected from both areas showed a remarkable divergence between the $\mathrm{CH} 2$ isolates, with
Keywords: evolutionary dynamics, genetic variability, mixed infections, PepMV, tomato, virus interaction
Viral diseases in crop plants result in important economic losses worldwide. Viral infections can be produced by either single or multiple viral species or strains. Mixed viral infections are indeed more common than previously thought, as evidenced by the use of novel molecular techniques (McLeish et al. 2019; Tollenaere et al. 2016). In particular, the advent of high-throughput sequencing techniques has allowed for the characterization of viromes from cultivated and wild plants, including the concurrent identification of novel viruses as well as several viral strains (Bernardo et al. 2018; Pagán 2018; Roossinck 2012). Both wild and cultivated plants are vulnerable to multiple infections by different viruses (Davino et al. 2008; Gil-Salas et al. 2012; Gómez et al. 2010; Juarez et al. 2013; Kassem et al. 2013; Tuomivirta and Hantula 2005) or different strains or genotypes of the same virus (Gómez et al. 2009; Moriones and Navas-Castillo 2008; Navas-Castillo et al. 2000; Rubio et al. 2001; Syller 2012; Taiwo et al. 2007).

In mixed infections, viruses can respond synergistically or antagonistically to the presence of other virus(es) in the same plant (Syller 2012) through a direct virus-virus interaction or an indirect host-mediated interaction (Tollenaere et al. 2016). The virus-virus interactions may affect viral traits that could change the evolutionary

†Corresponding author: P. Gómez; pglopez@cebas.csic.es

Funding: This work was supported by Ministry of Economy, Industry and Competitiveness (MINECO) of Spain research grants (AGL2014-59556-R and AGL2017-89550-R) and European Union European Regional Development Fund (FEDER) funds. C. Alcaide was supported by a MINECO PhD Programme grant (FPU16/02569)

*The $\boldsymbol{e}$-Xtra logo stands for "electronic extra" and indicates that one supplementary table is published online.

The author(s) declare no conflict of interest.

(c) 2020 The American Phytopathological Society dynamics of the viral populations (Ali and Roossinck 2017; Leeks et al. 2018; Roossinck 2012) compared with single infections. Thus, mixed infections may have far-reaching epidemiological consequences for at least one of the viruses involved in the infection. Despite its epidemiological relevance, little is known about how mixed infections affect viral genetic diversity compared with single infections in agricultural contexts, possibly because of the lack of potential comparative studies of single and mixed infections using viral populations under similar agroecological scales. This knowledge would allow us to understand how virus-virus interactions can shape the evolutionary dynamics of viral populations and would help in developing efficient viral disease control measures.

Tomato (Solanum lycopersicum) is a commercially important crop in the Mediterranean basin. Despite the considerable amount of pathological research on tomato infectious diseases, outbreaks of viral pathogens have become a major worldwide concern (Hanssen et al. 2010). For instance, one virus that hampers the intensive cultivation of tomato crop is pepino mosaic virus (PepMV). PepMV belongs to the genus Potexvirus (family Alphaflexiviridae) and is a single-stranded positive-sense RNA virus of approximately 6,400 base pairs. PepMV was reported as the causal agent of a viral disease on tomato crop in the Netherlands in 1999 (van der Vlugt et al. 2000). Thereafter, the virus spread rapidly through Europe and the rest of the world (European and Mediterranean Plant Protection Organization 2019; Werkman and Sansford 2010), causing epidemics and severe economic losses. PepMV is efficiently transmitted through contact, although it can also be transmitted by seeds, fungi, bumblebees, and irrigation water (Hanssen and Thomma 2010). In addition to tomato crops, PepMV has also been reported in other crop species, mainly in the Solanaceae family, such as pepino ( $S$. muricatum), aubergine ( $S$. melongena), potato (S. tuberosum), tobacco (Nicotiana tabacum), and basil (Ocimum basilicum), as well as in certain weed species (Gómez et al. 2012a; Hanssen and Thomma 2010). 
Similar to other potexviruses, the PepMV genome has five open reading frames (ORFs). ORF1 encodes the putative RNA-dependent RNA polymerase that contains three domains: a methyltransferase domain, an NTP binding site, and a polymerase domain (Aguilar et al. 2002). The triple gene block (TGB) is encoded by ORFs 2, 3, and 4 and is formed by three proteins: TGB1, TGB2, and TGB3. For potexviruses, TGB1 has been described as a protein with RNA binding activity (Morozov and Solovyev 2003) and different suppressor activities (Solovyev et al. 2012). TGB2 and TGB3 are able to direct TGB1 to plasmodesmata and the three proteins are involved in the movement of the virus (Morozov and Solovyev 2003; Tilsner et al. 2013). ORF5 encodes a coat protein (CP) involved in cell-to-cell and long-distance movement (Morozov and Solovyev 2003). Two untranslated regions flank the coding sequence, where a poly(A) tail is found at the $3^{\prime}$ end of the genomic RNA (Aguilar et al. 2002).

PepMV genetic variability is composed of six strains: the original Peruvian (LP) strain, the European (EU) strain, the North American (US1-CH1) strain, the North American recombinant (US2) strain (a recombinant between US1 and $\mathrm{CH} 1$ ), the Chilean ( $\mathrm{CH} 2)$ strain, and the new Peruvian (PES) strain (Hanssen and Thomma 2010; Moreno-Pérez et al. 2014). Only the EU, CH2, and US1 strains have been reported to infect tomato crops thus far (Blystad et al. 2015; Gómez-Aix et al. 2019). In Spain, at the outset of the outbreak during 2000 to 2004 , the PepMV populations were genetically homogeneous, comprising isolates that were highly similar to the EU strain (Pagán et al. 2006). Subsequently, between 2005 and 2008, PepMV populations in Murcia (southeastern Spain) were composed of cocirculating $\mathrm{CH} 2$ and EU types. The latest monitoring in 2017 in Spain indicated that the PepMV population has remained similar to the 2005 to 2008 period (Gómez-Aix et al. 2019), when $\mathrm{CH} 2$-type isolates were predominant and EU isolates were found mainly in mixed infections (Gómez et al. 2009; GómezAix et al. 2019). Although the persistence of single and mixed strain infections of PepMV is well documented, it remains unclear how the cocirculation of different viral strains could affect the genetic variability and evolutionary dynamics of the viral populations in plants. We aim to fill this knowledge gap by comparing a viral strain population with different types of infections from two geographically close areas over time.

We monitored the occurrence of PepMV in tomato plants in the two major tomato-producing areas in Murcia (southeastern Spain) in 2014 and 2015. In addition, we used previous data and samples collected in 2007 and 2008 to examine the genetic diversity of the PepMV-CH2 populations from one area with only single infections and another area with prolonged mixed infections. Moreover, using six PepMV-CH2 full-length infectious clones, we examined how PepMV-CH2 viral fitness is affected by the presence of the EU strain.

\section{MATERIALS AND METHODS}

Sample collection. During 2014 and 2015, a total of 320 apical tomato leaf samples showing virus-like symptoms to PepMV infection were collected from different greenhouses in two areas of Murcia (southeastern Spain): Mazarrón $\left(37^{\circ} 35^{\prime} 54^{\prime \prime} \mathrm{N}\right.$ $\left.1^{\circ} 18^{\prime} 50^{\prime \prime} \mathrm{O}\right)$ and Águilas $\left(37^{\circ} 24^{\prime} 15^{\prime \prime} \mathrm{N} 1^{\circ} 34^{\prime} 55^{\prime \prime} \mathrm{O}\right)$. In 2014 , a total of 140 samples were collected from Mazarrón (seven greenhouses) and 120 from Águilas (six greenhouses). In 2015, a total of 35 samples were collected from Mazarrón (six greenhouses) and 25 from Águilas (four greenhouses). All plant samples were stored frozen at $-80^{\circ} \mathrm{C}$. In addition, 16 and 30 tomato leaf samples representing the years 2007 and 2008, respectively, were retrieved from our previous tomato sample collection (Supplementary Table S1). Data from 2005, 2006, and 2017 were covered by a total of 134, 18, and 48 samples collected from Mazarrón and 0, 20, and 28 samples collected from Águilas, respectively (Gómez et al. 2009; Gómez-Aix et al. 2019). This allowed us to trace the prevalence of the single and mixed strain infections of PepMV in those two areas over time.
PepMV detection and occurrence. Total RNA from plant samples was extracted using TRI Reagent (Sigma-Aldrich, St. Louis, MO). The RNA from each sample was placed in duplicate on two positively charged nylon membranes and was fixed with an ultraviolet crosslinker. A dot-blot molecular hybridization was carried out using two specific RNA probes, one for PepMV-EU and another for PepMV-CH2 (Gómez et al. 2009; Gómez-Aix et al. 2019). The membranes were incubated overnight at $68^{\circ} \mathrm{C}$ with the specific digoxigenin-labeled probes (Pallás et al. 1998). After hybridization, a series of washes were carried out, followed by an incubation with antidigoxigenin antibody conjugated to phosphatase alkaline (Anti-Digoxigenin-AP; Roche Diagnostics, Mannheim, Germany) and CDP-Star chemiluminescent substrate (GE Healthcare UK Ltd., Buckinghamshire, UK) (Gómez-Aix et al. 2019). Finally, analyses of the membranes were performed using an Amersham Imager 600 chemiluminescent detector (GE Healthcare Bio-Sciences AB, Uppsala, Sweden).

PepMV amplification and sequencing. To be consistent with previous studies (Gómez et al. 2009), analysis of the PepMV genomic fragment included the TGB and the CP gene. For 2007, we randomly selected three and four PepMV-CH2-positive tomato leaf samples from the Mazarrón and Aguilas areas, respectively. The respective numbers were 7 and 15 for 2008 and 35 and 27 for 2014. Thus, a total of 45 samples from Mazarrón and 46 from Águilas were retrotranscribed using reverse transcription (Roche). The sequences corresponding to the TGB and CP (Gómez-Aix et al. 2019) were amplified using the Expand High Fidelity PCR System (Roche) following the manufacturer's protocol, with $52^{\circ} \mathrm{C}$ as the annealing temperature. The amplified $(2.2 \mathrm{~kb})$ genomic fragments of PepMV were visualized in a $0.7 \%$ agarose gel through electrophoresis and cleaned up using the GeneClean kit (MP Biomedicals, Illkirch, France). The purified fragments were cloned into the pGEM-T-Easy vector following the manufacturer's recommendations and using TOP10 electrocompetent Escherichia coli cells. One cDNA clone was randomly chosen for each sample from 2007 and 2008, and two clones were chosen for each sample from 2014. A total of 153 cDNA clones were sequenced using the Sanger method with primers described in a previous study (Gómez et al. 2009) by an external sequencing service (STAB VIDA, Caparica, Portugal).

Phylogenetic and genetic diversity analysis. Phylogenetic relationships were inferred from 106 randomly selected PepMV sequences. For 2007 and 2008, we used 6 and 11 sequences (accession numbers FJ263349 to FJ263365) from a previous study (Gómez et al. 2009) and added 10 and 19 new sequences, respectively. From 2014, we used 60 sequences that were randomly chosen from all PepMV samples sequenced in that year $(n=124)$. A phylogenetic tree was constructed using those sequences and a reference PepMV-CH2 sequence (accession number KJ018165) using MEGA7 software (Kumar et al. 2016). The best DNA model was selected using maximum likelihood estimation and the evolutionary history was inferred by the maximum likelihood method, based on the general time reversible model and with 1,000 bootstrap replicates. A discrete gamma distribution was used to model evolutionary rate differences among sites (five categories; $+\mathrm{G}$, parameter $=0.7568$ ) and the rate variation model allowed some sites to be evolutionarily invariable $([+\mathrm{I}], 60.33 \%$ sites $)$. The strength of the natural selection was estimated by measuring the number of nonsynonymous substitutions per nonsynonymous site $(\mathrm{dN})$ and the number of synonymous substitutions per synonymous site (dS). A dN/dS ratio approximately equal to 1 indicates neutral evolution, $<1$ indicates negative or purifying selection, and $>1$ indicates positive or adaptive selection. Finally, DnaSP6 software (Rozas et al. 2017) was used to assess genetic diversity $(\pi)$ and the gene flow index (Fst) in the subpopulations from different areas and years using the 106 PepMV sequences (without the reference sequence). Note that Fst values can range from 1 to 0 , meaning complete or no 
population differentiation, respectively, as a result of the gene flow between populations.

Construction of full-length PepMV-CH2 infectious clones. Six PepMV-infected tomato samples were randomly selected among 2014 samples to carry out construction of fulllength PepMV-CH2 infectious clones. Three PepMV-CH2 isolates were from single infections from Águilas (AG1, AG2, and AG3) and three isolates were from mixed infections (PepMV$\mathrm{CH} 2$ and PepMV-EU) from Mazarrón (MZ1, MZ2, and MZ3). Retrotransciption was performed using reverse transcription (Roche) with a specific poly(T) primer. Then PepMV-CH2 complete genomes were amplified with Phusion High-Fidelity DNA Polymerase (Thermo Fisher Scientific, Waltham, MA) following the manufacturer's recommendations and using specific primers for PepMV-CH2 with an overlapping sequence of the $\mathrm{pJL}$ 89 vector (Blawid and Nagata 2015). The primers were CE-1947 forward $(\mathrm{Fw}) 5^{\prime}$-catttcatttggagagggaaaacaaaacataacacataatatca$3^{\prime}$ and CE-1948 reverse (Rv) 5'-atgccatgtcgaccc(t)30cataaattta gata-3' (vector sequences are underlined). The pJL 89 vector was amplified with specific primers (Blawid and Nagata 2015) also using Phusion High-Fidelity DNA Polymerase (Thermo Scientific). The amplified approximately 6,400-bp (PepMV genome) and 4,700-bp (pJL 89 vector) fragments were purified from a $0.7 \%$ agarose gel with the GeneClean kit. PepMV genomes were cloned into the pJL 89 vector using Gibson Assembly Master Mix (New England Biolabs Inc., Ipswich, MA) (Blawid and Nagata 2015; Gibson 2009) following the manufacturer's protocol. After Gibson Assembly cloning, Stellar competent E. coli cells (Clontech Laboratories) were transformed, and plasmids were purified and verified using a restriction enzyme. Then, the six PepMV full-length genomes were sequenced using the Sanger method (STAB VIDA).

Agroinoculation and purification of virions. The Agrobacterium tumefaciens $\mathrm{C} 58 \mathrm{C} 1$ strain was individually transformed with each of the purified plasmids that contained different PepMV-CH2 isolates and also the PepMV-Sp13 isolate (Aguilar et al. 2002). The cultures were incubated overnight, centrifuged, and resuspended into the same volume of MES buffer (Sempere et al. 2011). N. benthamiana plants were agroinfiltrated by mixing each Agrobacterium culture containing a PepMV genome with an Agrobacterium culture containing the $\mathrm{pBP} 19$ vector at a $3: 1$ ratio. Plants were maintained in a growth chamber (16-h photoperiod, $22^{\circ} \mathrm{C}$ ); after 15 days postinoculation (dpi), plant material was collected and virions of each PepMV isolate were purified. The plant material was homogenized following a described protocol (AbouHaidar et al. 1998; Agirrezabala et al.

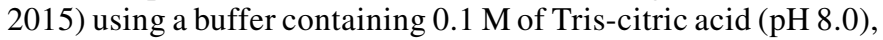
$0.2 \%$ 2-mercaptoethanol, $0.01 \mathrm{M}$ of sodium thioglycolate, and $1 \% \mathrm{vol} / \mathrm{vol}$ Triton $\mathrm{X}-100$. Chloroform was added ( $25 \% \mathrm{vol} / \mathrm{vol})$ and after a brief centrifugation, PEG 6000 was used to precipitate the virions. A series of centrifugations were performed and the virus concentration was determined by measuring the optical density at $260 \mathrm{~nm}$, using an extinction coefficient of 2.9 (AbouHaidar et al. 1998).

Plant inoculation and viral fitness estimation. Five healthy tomato plants (cultivar Moneymaker) were mechanically mock inoculated and PepMV inoculated with virions from each of the six full-length PepMV-CH2 clones in single and mixed infections with the PepMV-EU clone (PepMV-Sp13) (Aguilar et al. 2002). The inoculations were carried out in carborundum sprinkled cotyledons using $25 \mu \mathrm{l}$ of each purified virion per plant at

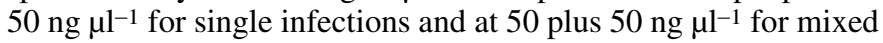
infections in $30 \mathrm{mM}$ of sodium phosphate buffer ( $\mathrm{pH} 8$ ). Plants were grown in a greenhouse (16-h photoperiod and $26 / 22^{\circ} \mathrm{C}$ in a day/ night cycle) and systemic leaves were collected after 7 dpi. Total RNA was extracted using TRI Reagent, purified by phenolchloroform extraction, and treated with DNaseI (Sigma-Aldrich). Then viral accumulation was estimated by absolute reverse transcription quantitative PCR using the One-step NZYSpeedy RT-qPCR Green Kit and ROX Plus (NZYTech, Lisboa, Portugal) with specific primers for PepMV-CH2 (CE-2459 Fw 5'-gctagttg cagctaccttcaac-3' and CE-2460 Rv 5'-ttgttatcagcagccttggg- $3^{\prime}$ ) and for PepMV-EU (described in Gómez et al. 2009). The standard curve was prepared using six serial dilutions of viral RNA obtained from disassembled $\mathrm{CH} 2$ and $\mathrm{EU}$ virions. Then the viral growth rate was computed using the Malthusian parameter, following the equation:

$$
m=(1 / t) \log (Q)
$$

where $Q$ is the amount of PepMV RNA in nanograms per $100 \mathrm{ng}$ of total plant RNA and $t$ is the number of days after inoculation (Lalić et al. 2011; Moreno-Pérez et al. 2016). Finally, viral fitness was calculated as

$$
W=e^{m}
$$

where $e$ is the base of the natural logarithms (Crow and Kimura 1970; Moreno-Pérez et al. 2016), and relative fitness was estimated following the expression:

$$
W_{\text {mix }} / W_{\text {single }}
$$

Statistical analyses. A two-way analysis of variance (ANOVA) was carried out to study the significant differences in $\mathrm{dN}$ and $\mathrm{dS}$ values between the areas and years, and a one-way ANOVA was performed to study the accumulation and relative fitness between the PepMV-CH2 clones. All analyses were performed in IBM SPSS Statistics 24 software.

Nucleotide sequence accession numbers. The PepMV-CH2 partial sequences were deposited in GenBank under the accession numbers FJ263349 to FJ263365 and MK860441 to MK860593. Full-length PepMV-CH2 genome sequences of the infectious clone isolates were deposited under the accession numbers MN038405 to MN038410.

\section{RESULTS}

PepMV occurrence in tomato crops. Molecular dot-blot hybridization indicated that most of the plants (98.8\%) affected by PepMV from Mazarrón and Águilas appeared to be infected with PepMV-CH2 isolates. However, PepMV occurrence differed between the areas. In Águilas, only single PepMV infections were observed in 2014, with all PepMV isolates belonging to the PepMV$\mathrm{CH} 2$ strain (Fig. 1), whereas no PepMV infections were detected in 2015. In Mazarrón, single PepMV-EU (2\%) and PepMV-CH2 (39.4\%) infections, as well as mixed infections of both strains (EU+CH2, 58.4\%), were observed in 2014. In 2015, most of the $\mathrm{CH} 2$ isolates appeared to be in single infections $(81.5 \%)$ with a few EU isolates in mixed infections (18.5\%). By gathering data from previous studies, we were able to cover a period of 13 years and found a remarkable consistency in PepMV infections in both tomato-producing areas since the $\mathrm{CH} 2$ strain emerged in 2005. Single infections were found in Águilas and mixed strain infections remained in Mazarrón (Fig. 1).

Phylogenetic and genetic variability of the PepMV-CH2 populations. To determine whether the genetic variability of PepMV-CH2 populations was different between both areas, 106 $\mathrm{CH} 2$ isolates were randomly selected from Águilas (53 sequences) and Mazarrón (53 sequences) representing different years. Phylogenetic analysis revealed two separate clades with a marked differentiation between the areas with the exception of four isolates from Águilas and three from Mazarrón (Fig. 2). The difference between the Mazarrón and Águilas populations was also indicated by estimation of the interpopulation genetic differentiation value 
$($ Fst $=0.375)($ Table 1$)$. Next, we examined the strength of selection operating in the PepMV-CH2 subpopulations (areas and years) at the nucleotide level. The PepMV population in Águilas displayed a lower averaged number of segregating sites $(S=55)$ and lower nucleotide diversity $(\pi=0.005)$ than the PepMV population in Mazarrón ( $\mathrm{S}=115$ and $\pi=0.013$ ) (Table 1 ). Moreover, the $\mathrm{dN} / \mathrm{dS}$ ratio was approximately 0.3 for both populations (Table 1 ), indicating that the four sequenced genomic regions (TGB and $\mathrm{CP}$ gene) were under purifying selection in both areas. Although the $\mathrm{dN}$ values did not differ significantly between the areas $\left(F_{1,6}=\right.$ 4.12, $P=0.112)$, Mazarrón exhibited significantly $\left(F_{1,6}=23.72\right.$, $P=0.008)$ higher dS values $(0.025$ to 0.030$)$ than Águilas $(0.004$ to 0.016) in each year (Table 1). This indicated increased intrapopulation genetic variability at the nucleotide site in the Mazarrón population.

Fitness estimation of $\mathrm{CH} 2$ isolates coming from both areas. To further study whether the $\mathrm{CH} 2$ isolates from Mazarrón could respond differentially with respect to those from Águilas, as result of a selection process imposed by the presence of the EU type in that area, we first carried out the construction of full-length cDNA infectious clones; three $\mathrm{CH} 2$ isolates from Águilas (AG1, AG2, and AG3) and three isolates from Mazarrón (MZ1, MZ2, and MZ3) were compared. The sequence analysis showed that $\mathrm{CH} 2$ isolates from each area cluster together on the phylogenic tree (Fig. 3A), which was consistent with the previous phylogenetic results. We then used those clones to examine their viral accumulation in single infected tomato plants, and we found that viral accumulation did not differ significantly between the MZ1 to MZ3 and AG1 to AG3 isolates $\left(F_{1,6}=0.179, P=0.694\right)$ (Fig. 3B). Yet the accumulation of the $\mathrm{CH} 2$ isolates was two orders of magnitude higher than the accumulation of the Sp13 (EU type) isolate in single infections, as expected (Fig. 3B). We next estimated the viral fitness of each PepMV-CH2 clone in the absence and in the presence of the PepMV-Sp13 (EU type) in tomato, and we observed that those PepMV-MZ(1 to 3) and PepMV-AG(1 to 3) isolates had a significant decrease in fitness in the mixed infections $\left(F_{1,12}=\right.$ 14.44, $P=0.004$ ) (Fig. 4; relative fitness value $<1$ ), reflecting an antagonistic interaction between the PepMV-CH2 and EU isolates. However, this average $\mathrm{CH} 2$ fitness cost associated with the presence of the EU isolate was irrespective of the $\mathrm{CH} 2$ origin $\left(F_{1,12}=0.230, P=0.640\right)$, suggesting that $\mathrm{CH} 2$ populations from Mazarrón and Águilas may respond equally to the presence of the EU type.

\section{A}

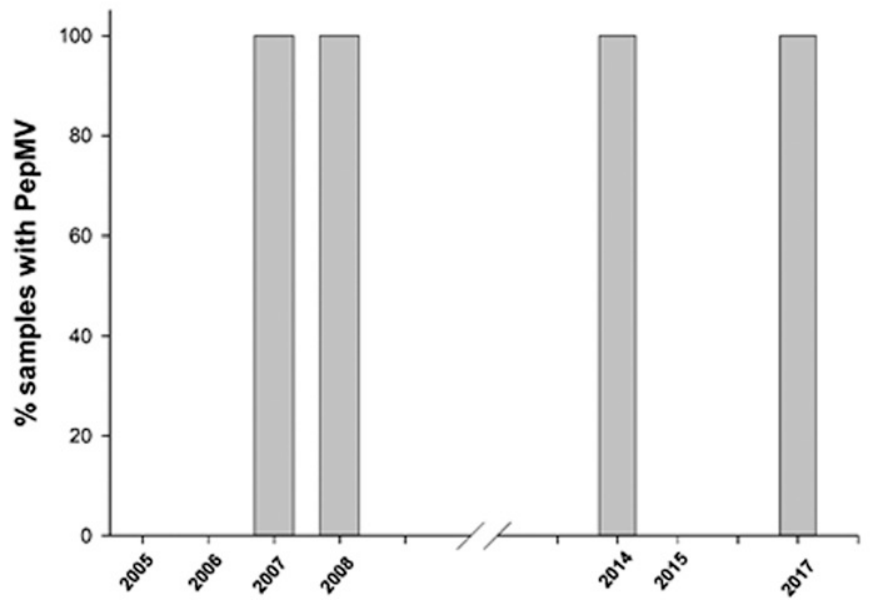

\section{DISCUSSION}

In this work, we compared PepMV populations in different years from two geographically close areas (Águilas and Mazarrón) in southeastern Spain, where two different patterns of infection (single and mixed infections) were found. Only single infections of PepMV-CH2 were found in Águilas, whereas both single and mixed (CH2 and EU) PepMV infections were found in Mazarrón. This long-term occurrence of PepMV strains provided us a field study design to compare PepMV populations, examining how the cocirculation of different viral strains during concurrent and sequential infections may affect the genetic variability and evolutionary dynamics of the viral populations.

Multiple infections by different strains of the same species are common, and their interactions have been shown to play an important role in their prevalence in naturally infected hosts (Balmer and Tanner 2011; Gómez et al. 2009). RNA plant virus populations are characterized by their capacity to generate genetic diversity as a consequence of a combination of factors, such as elevated mutation and recombination rates, large population sizes, and short generation times (Pagán and García-Arenal 2018). It would be reasonable to expect that interacting viruses within the same host may affect the molecular mechanisms that shape the genetic diversity in the viral populations, thus influencing the emergence and prevalence of virus species/genotypes, which is epidemiologically relevant for determining the population structure and evolutionary dynamics. Mixed strain infections create an environment that may favor recombination, and consequently, the appearance of genetic variants that may evolve into novel genotypes or strains (Froissart et al. 2005; Montville et al. 2005; Moriones and Navas-Castillo 2008). This may occur in the PepMV populations (Hanssen and Thomma 2010) and, in fact, two recombinant isolates of PepMV-EU and PepMV-CH2 were found in 2004 (Pagán et al. 2006). However, they seemed not to be favored in the virus population, as we did not find any PepMV recombinants in our field tomato surveys since 2005. In addition, a recent experimental evolution assay showed that no recombinant variants were found after passaging isolates from both $\mathrm{EU}$ and $\mathrm{CH} 2$ strains in mixed infected tomato plants (Agüero et al. 2018). Thus, instead of recombination, we suggest that the predominant mechanism contributing to the genetic variability within the PepMV populations is mutation. Through the mutational process, RNA viruses create extensive within-host populations that may contain a large

B
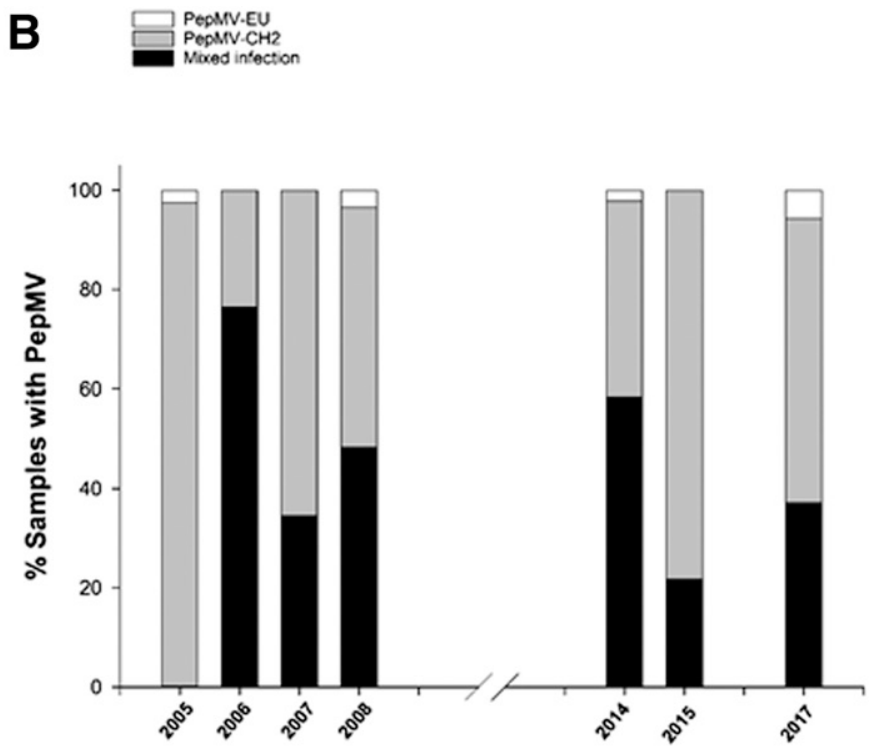

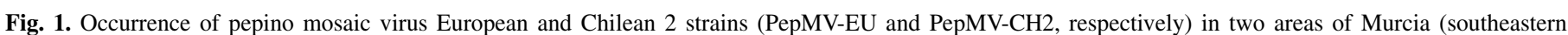

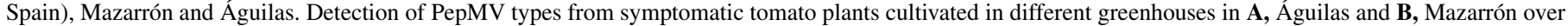
a period of 13 years. Data from 2005 to 2008 were obtained from a previous study (Gómez et al. 2009), similar to data for 2017 (Gómez-Aix et al. 2019). 
Tree scale: 0.01

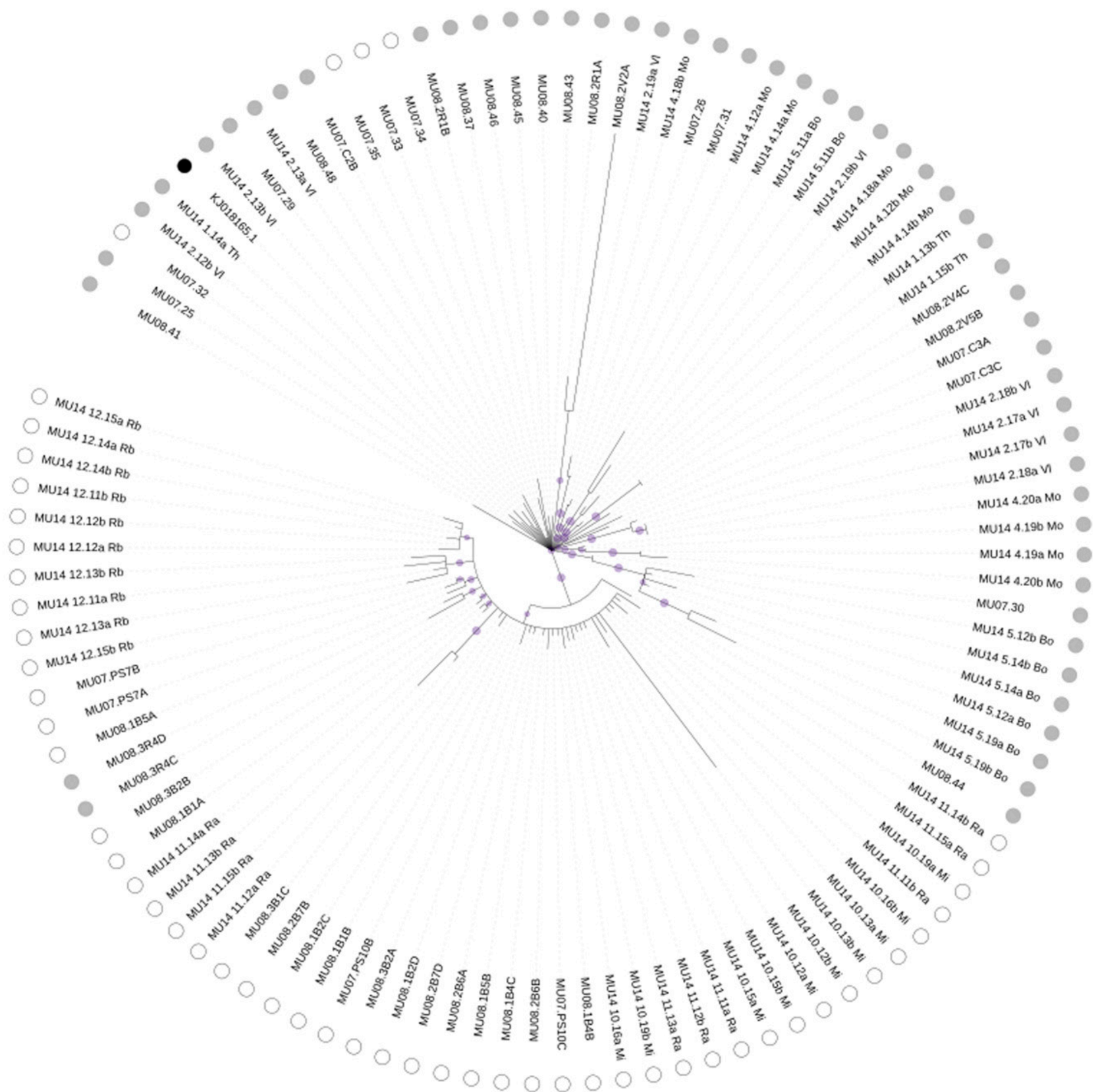

Fig. 2. Phylogenetic relationships based on the triple gene block and coat protein gene sequences of pepino mosaic virus Chilean 2 isolates collected in 2007 , 2008, and 2014. The phylogenetic tree was built by the maximum likelihood method with 1,000 bootstrap replications and using the general time reversible model. Only branches with bootstrap values $>70 \%$ are shown (marked with purple (gray) circles of different sizes). Genetic distances are presented as the lengths of the branches. The isolates are labeled with the collection year and colored according to the sampling area (Mazarrón, gray; and Águilas, white). The Genbank reference isolate is marked in black.

TABLE 1. Pepino mosaic virus Chilean 2 population genetic parameters in two tomato-producing areas and different years ${ }^{\mathrm{a}}$

\begin{tabular}{|c|c|c|c|c|c|c|c|c|c|c|c|c|}
\hline \multirow[b]{3}{*}{ Year } & \multirow[b]{3}{*}{ Area } & \multirow[b]{3}{*}{$\mathrm{S}(n)$} & \multirow[b]{3}{*}{$\pi$} & \multirow[b]{3}{*}{$\mathrm{dS}$} & \multirow[b]{3}{*}{$\mathrm{dN}$} & \multirow[b]{3}{*}{$\mathrm{dN} / \mathrm{dS}$} & \multicolumn{6}{|c|}{ Fst } \\
\hline & & & & & & & \multicolumn{2}{|c|}{2007} & \multicolumn{2}{|c|}{2008} & \multicolumn{2}{|c|}{2014} \\
\hline & & & & & & & Águilas & Mazarrón & Águilas & Mazarrón & Águilas & Mazarrón \\
\hline & Mazarrón & 60 & 0.011 & $0.025 \pm 0.004$ & $0.005 \pm 0.001$ & 0.200 & 0.192 & - & & & & \\
\hline \multirow[t]{2}{*}{2008} & Águilas & 23 & 0.002 & $0.004 \pm 0.001$ & $0.001 \pm 0.000$ & 0.250 & 0.264 & 0.583 & - & & & \\
\hline & Mazarrón & 122 & 0.016 & $0.030 \pm 0.004$ & $0.011 \pm 0.001$ & 0.367 & 0.084 & 0.081 & 0.382 & - & & \\
\hline 2014 & Águilas & 103 & 0.006 & $0.008 \pm 0.001$ & $0.004 \pm 0.001$ & 0.500 & 0.229 & 0.516 & 0.277 & 0.337 & - & \\
\hline
\end{tabular}

${ }^{a} \mathrm{~S}=$ segregating sites, $\pi=$ nucleotide diversity, $\mathrm{dS}=$ synonymous substitutions per synonymous site, $\mathrm{dN}=$ nonsynonymous substitutions per nonsynonymous site, and $\mathrm{Fst}=$ gene flow index among subpopulations. Values for $\mathrm{dS}$ and $\mathrm{dN}$ are presented as the mean $\pm \mathrm{SD}$. 
amount of sequence diversity, which in turn is linked to the evolvability and adaptability of viral populations to challenging conditions (Poirier and Vignuzzi 2017; Vignuzzi et al. 2006). Taking into account that the PepMV molecular evolution rate has been reported to be $5.57 \times 10^{-3}$ substitutions per site per year, a value that is approximately an order of magnitude higher than the rates reported for other plant RNA viruses (Gómez et al. 2012b), it might be expected that PepMV genetic diversity will be shaped by purifying or directional selection rather than random genetic drift.

Although our aim was not to explain the causes of the different patterns of PepMV infections in the two tomato-producing areas, it is surprising that no PepMV-EU infections were found in Águilas. This lack of EU isolates may have been caused by the effect of the specific cropping practices and tomato cultivars, since there are no overlapping growing seasons and most of the cultivars are grafted, although it may also be influenced by the presence of alternative hosts (cultivated and wild plants), among others. Regardless of the causes of this epidemiological pattern, the interplay of these factors, either individual or combined, is supported by the low genetic flow observed between viral populations from Águilas and Mazarrón. This low connectivity or migration between the areas is suggested by the Fst index, which showed moderate genetic differentiation (Fst $=0.374)$ despite the tomato-producing areas being geographically close. In fact, the Fst index was at the same level as for two geographically distant areas such as Tenerife and Morocco $(F s t=0.35)$ or Granada and Morocco $(F s t=0.26)($ Gómez-Aix et al.

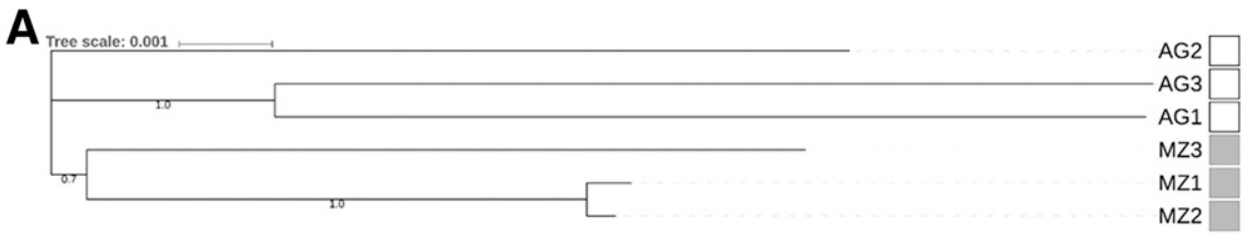

B

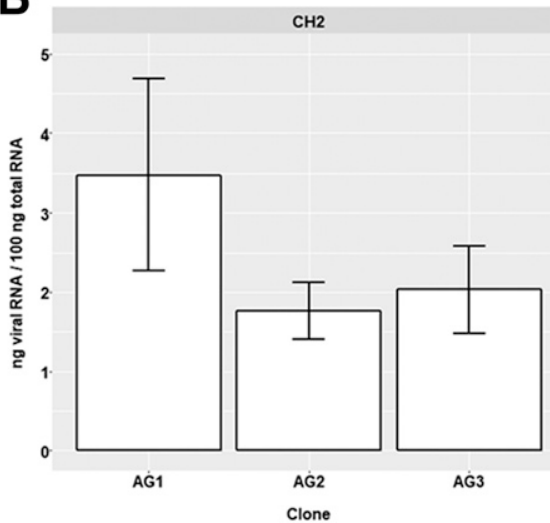

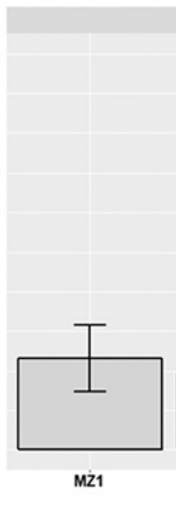

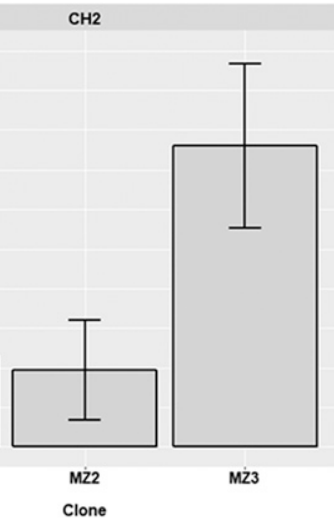

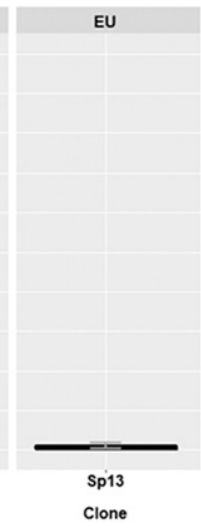

Fig. 3. A, Phylogenetic tree of the full-genome sequences of the six pepino mosaic virus Chilean 2 (PepMV-CH2) infectious clones. The tree was constructed based on the genetic distances and using the maximum likelihood method. The $\mathrm{CH} 2$ isolates from Águilas (AG1, AG2, and AG3) are marked in white, and Mazarrón (MZ1, MZ2, and MZ3) are shown in gray. B, Viral accumulation of PepMV isolates in single infections. Viral accumulation of each clone was inferred by absolute quantification reverse transcription quantitative PCR using specific primers for the $\mathrm{CH} 2$ and European (EU) types with three technical replicates and standard curves from disassembled virions. The accumulation of each isolate was estimated from single inoculated tomato plants $(n=5)$ after 7 days postinoculation. Bars are the mean $\pm \mathrm{SD}$ of the RNA accumulation for the CH2 isolates from Águilas (AG-1-3, in white), Mazarrón (MZ1-3, in gray), and the EU isolate (Sp13, in black).

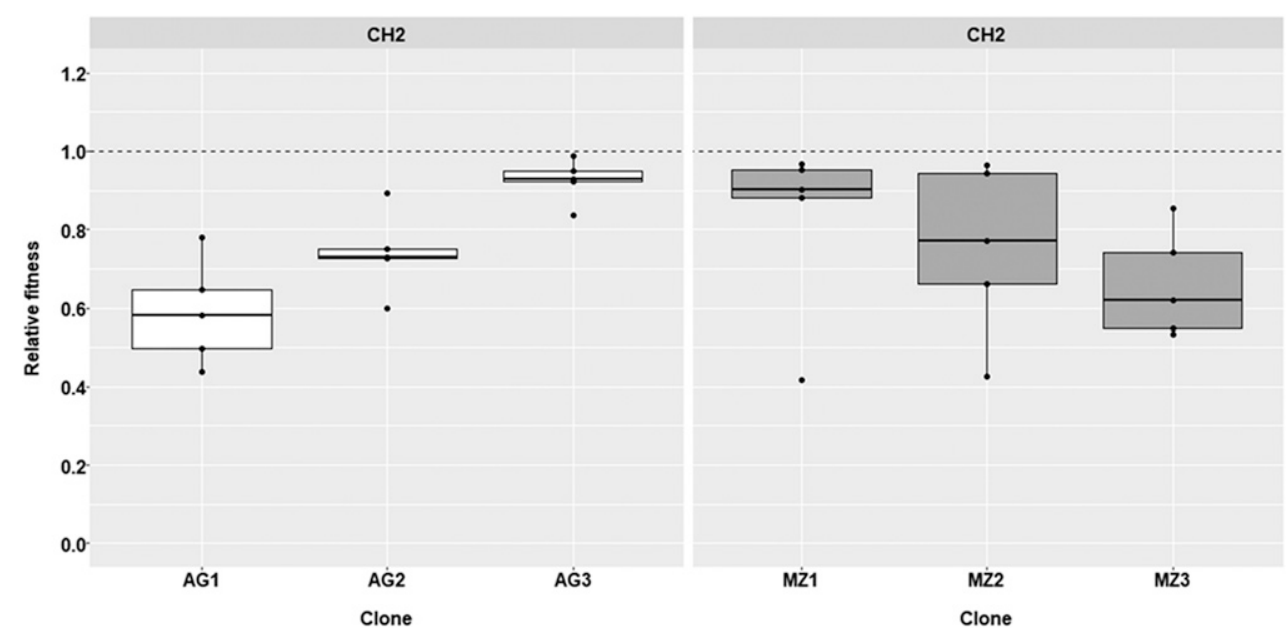

Fig. 4. Relative fitness estimation of the pepino mosaic virus Chilean 2 (PepMV-CH2) infectious clones. The relative fitness value of each CH2 clone, AG1 to AG3 (marked in white), and MZ1 to MZ3 (in gray) is represented as a boxplot, showing the minimum and maximum value, the median, the first and third quartile, and outliers. Viral fitness was inferred by absolute quantification reverse transcription quantitative PCR using specific primers for the $\mathrm{CH} 2$ type with three technical replicates and a standard curve using disassembled virions. Fitness was estimated using the Malthusian parameter from single and mixed infected tomato plants $(n=5)$ after 7 days postinoculation, and then relative fitness was calculated by the ratio of the viral fitness average value from single infections to each fitness value in mixed infections $\left(W_{m i x} / W_{\text {single }}\right.$ ). Values $<1$ indicate a fitness cost associated with the presence of the European type. 
2019). This genetic differentiation between the two geographically close areas was also supported by the phylogenetic analysis (Fig. 2). Interestingly, although synonymous substitutions were more abundant than nonsynonymous substitutions in both areas, the Mazarrón sequences had more segregating sites and greater nucleotide diversity compared with Águilas. These results suggest that purifying selection is the main force contributing to divergence within the $\mathrm{CH} 2$ populations. These results are in agreement with a previous study for the PepMV population in Murcia (Gómez et al. 2009), in which the majority of nucleotide substitutions in the population were synonymous, with a purifying selection acting on the populations from 2005 to 2008. This purifying selection operating on that genomic region is also consistent with the potential invariance of the genome of RNA viruses, whereas mutations appear to be either lethal or deleterious (Carrasco et al. 2007). Thus, it is possible that the polymorphic changes observed in this study are deleterious mutations segregating in the population, presumably as a result of the dynamic interactions between the two cocirculating PepMV strains. This could lead to changes in the viral evolutionary rate, which may theoretically constrain the functionality of the viral proteins, affecting viral replication and reinforcing the selection pressure in the mixed infections (Nee 2016). As a case in point, Zhang et al. (2019) showed that the P10 protein of rice black-streaked dwarf virus can act as an effector during an infection modulating the virus through a synergistic or antagonistic interaction with a related or unrelated virus. This opens future studies to identify the multifunctionality of viral proteins under mixed infection conditions. As mentioned before, it is worth highlighting that in addition to cropping practices and cultivar details, ecological conditions are also particularly important for explaining the evolutionary dynamics of PepMV in tomato crops (Moreno-Pérez et al. 2014, 2016; Pagán 2018; Pagán and García-Arenal 2018), and future studies should combine the coincident biotic interaction effects to abiotic factors.

Beyond the epidemiological circumstances that allow the longterm coexistence of PepMV strains, we speculated that the differentiation observed between the areas with different types of infection might be explained by the response of the $\mathrm{CH} 2$ type to the presence of the EU type when they coinhabit one tomato plant. The complex within-host virus-virus interactions may impair the fitness of the viruses compared with single infections.

Coinfection of plant viruses is characterized by either an antagonistic or synergistic interaction (Syller 2012; Syller and Grupa 2016). The antagonistic interaction has been associated with related viruses whose viral populations tend to be spatially separated at the cellular level (Dietrich and Maiss 2003; Laufer et al. 2018; Syller and Grupa 2016). Based on the accumulation of viral RNA, an asymmetric antagonistic interaction between EU and $\mathrm{CH} 2$ strains was suggested previously, in which the $\mathrm{CH} 2$ strain had lower RNA accumulation in coinfected tomato plants than in the single infected tomato plants (Gómez et al. 2009). The relative importance by which these PepMV strains could interact within the same host may depend on the extent to which they infect different tissues or coinfect the same cells. It is likely that the spatial structure of plants, in addition to the multiplicity of infection of each virus, could affect the distribution and temporality of viruses coinfecting the same plant, which in turn may modulate intrahost competition and adaptive evolution at the cellular level (Campos et al. 2008; Cuevas et al. 2003; Gonzalez-Jara et al. 2009; Gutiérrez et al. 2015; Lafforgue et al. 2011; Ojosnegros et al. 2010). This highlights the importance of understanding the mechanism behind virus-virus interactions in the same host, and further research is needed to simultaneously localize different species/genotypes infecting at cellular and tissue scales.

Our concern was also how the mixed infections of PepMV persisted only in the Mazarrón area. Our results suggest that both biotic interactions and natural selection can play an important role in the coexistence of viral strains. Fitness of the $\mathrm{CH} 2$ type was reduced by the presence of the EU type, whereas the EU type maintained its fitness, leading to the coexistence. Notably, the occurrence of different isolates within a single plant has been reported for other potexviruses. For example, six isolates of plantago asiatica mosaic virus with genomic and biological differences were isolated from a single lily plant (Komatsu et al. 2008). In addition, four distinct cDNA clones were derived from the same potexvirus isolate, alternanthera mosaic virus-SP, infecting a single $N$. benthamiana plant. Those different clones were then examined to identify determinants of the RNA accumulation and symptom severity (Lim et al. 2010). By contrast, an illustrative example of unsuccessful long-term coexistence is the evaluation of the tobacco mottle green mosaic virus and tobacco mosaic virus coinfection. In this case, deleterious mutations were not eliminated by selection and they thus accumulated, resulting in mutational extinction (Fraile et al. 1997). We further speculate that the EU strain could be imposing a selective pressure on the $\mathrm{CH} 2$ populations that results in the increase of the fitness of $\mathrm{CH} 2$ rare variants, possibly through negative frequency-dependent selection. Hence, this might promote within-host $\mathrm{CH} 2$ molecular variability during mixed infections. Consequently, if the rare variants could be maintained through selection, the new variants may be more likely to evolve and adapt, which should leave a phenotypic signature in the $\mathrm{CH} 2$ isolates. This phenotypic signature could result in changes in viral accumulation and virulence (Alizon et al. 2013), among others. However, and despite our results indicating a clear phylogenetically separation of the full genomes of the $\mathrm{CH} 2$ infectious clones (Fig. 3A), the $\mathrm{CH} 2$ fitness response did not depend on the $\mathrm{CH} 2$ origin (Fig. 4). This suggested that the presence of the EU type resulted in an antagonistic interaction without a concomitant phenotypic signature on these $\mathrm{CH} 2$ isolates. These results could in part be explained by the fact that the magnitude of this antagonistic interaction may also be modulated by either viral isolate plasticity or host ecology, as well as the order of infection, which could even disfavor the coexistence of viral genotypes, as one genotype may benefit more than the other in mixed infections. Alternatively, viruses may not only evolve within hosts, but also between hosts, and the effect of mixed infections on genetic diversity will also depend on the frequency of mixed infections and successes of the reinfections among hosts, although these issues still need further research.

In conclusion, our comparative study suggests that competitive interactions between PepMV strains could be driving the molecular variability of the PepMV-CH2 populations, and both competitive interactions and selection may be favoring the long-term coexistence of the EU and $\mathrm{CH} 2$ strains in tomato crops. These results may have implications for understanding the long-term prevalence of viral strains on plant crops and its effects on the evolutionary dynamics of the viral populations. Therefore, within-host virusvirus interactions, in addition to agricultural and environmental factors, should be considered in future research of plant viral diseases to better understand the structure and evolutionary dynamics of viral populations.

\section{ACKNOWLEDGMENTS}

We thank all technicians from each tomato-producing area for assisting during sample collections. We also thank C. Gómez-Aix and M. A. Sanchez-Pina for helpful comments, M. C. Montesinos for technical assistance, and Mario Fon for English editing assistance.

\section{LITERATURE CITED}

AbouHaidar, M. G., Xu, H., and Hefferon, K. L. 1998. Potexvirus isolation and RNA extraction. Pages 131-143 in: Plant Virology Protocols: From Virus Isolation to Transgenic Resistance. G. D. Foster and S. C. Taylor, eds. Humana Press, Totowa, NJ.

Agirrezabala, X., Méndez-López, E., Lasso, G., Sánchez-Pina, M. A., Aranda, M., and Valle, M. 2015. The near-atomic cryoEM structure of a flexible 
filamentous plant virus shows homology of its coat protein with nucleoproteins of animal viruses. eLife 4:e11795.

Agüero, J., Gómez-Aix, C., Sempere, R. N., García-Villalba, J., García-Núñez, J., Hernando, Y., et al. 2018. Stable and broad spectrum cross-protection against pepino mosaic virus attained by mixed infection. Front. Plant Sci. 9:1810.

Aguilar, J. M., Hernández-Gallardo, M. D., Cenis, J. L., Lacasa, A., and Aranda, M. A. 2002. Complete sequence of the Pepino mosaic virus RNA genome. Arch. Virol. 147:2009-2015.

Ali, A., and Roossinck, M. J. 2017. Analysis of quasispecies variation in single and mixed viral infection. Virus Evol. 3:vex037.

Alizon, S., de Roode, J. C., and Michalakis, Y. 2013. Multiple infections and the evolution of virulence. Ecol. Lett. 16:556-567.

Balmer, O., and Tanner, M. 2011. Prevalence and implications of multiplestrain infections. Lancet Infect. Dis. 11:868-878.

Bernardo, P., Charles-Dominique, T., Barakat, M., Ortet, P., Fernandez, E., Filloux, D., et al. 2018. Geometagenomics illuminates the impact of agriculture on the distribution and prevalence of plant viruses at the ecosystem scale. ISME J. 12:173-184.

Blawid, R., and Nagata, T. 2015. Construction of an infectious clone of a plant RNA virus in a binary vector using one-step Gibson Assembly. J. Virol. Methods 222:11-15.

Blystad, D. R., van der Vlugt, R., Alfaro-Fernández, A., del Carmen Córdoba, M., Bese, G., Hristova, D., et al. 2015. Host range and symptomatology of Pepino mosaic virus strains occurring in Europe. Eur. J. Plant Pathol. 143: 43-56.

Campos, P. R. A., Neto, P. S. C. A., De Oliveira, V. M., and Gordo, I. 2008. Environmental heterogeneity enhances clonal interference. Evolution (N. Y.) 62:1390-1399.

Carrasco, P., de la Iglesia, F., and Elena, S. F. 2007. Distribution of fitness and virulence effects caused by single-nucleotide substitutions in Tobacco etch virus. J. Virol. 81:12979-12984.

Crow, J. F., and Kimura, M. 1970. An Introduction to Population Genetics Theory. Harper \& Row Publishers, New York, NY.

Cuevas, J. M., Moya, A., and Elena, S. F. 2003. Evolution of RNA virus in spatially structured heterogeneous environments. J. Evol. Biol. 16:456-466.

Davino, S., Davino, M., Bellardi, M. G., and Agosteo, G. E. 2008. Pepino mosaic virus and Tomato chlorosis virus causing mixed infection in protected tomato crops in Sicily. Phytopathol. Mediterr. 47:35-41.

Dietrich, C., and Maiss, E. 2003. Fluorescent labelling reveals spatial separation of potyvirus populations in mixed infected Nicotiana benthamiana plants. J. Gen. Virol. 84:2871-2876.

European and Mediterranean Plant Protection Organization. 2019. EPPO Global Databases. https://gd.eppo.int.

Fraile, A., Escriu, F., Aranda, M.A., Malpica, J.M., Gibbs, A.J. and Garcia-Arenal, F. 1997. A century of tobamovirus evolution in an Australian population of Nicotiana glauca. J. Virol. 71:8316-8320.

Froissart, R., Roze, D., Uzest, M., Galibert, L., Blanc, S., and Michalakis, Y. 2005. Recombination every day: Abundant recombination in a virus during a single multi-cellular host infection. PLoS Biol. 3:e89.

Gibson, D. G. 2009. Synthesis of DNA fragments in yeast by one-step assembly of overlapping oligonucleotides. Nucleic Acids Res. 37:6984-6990.

Gil-Salas, F. M., Peters, J., Boonham, N., Cuadrado, I. M., and Janssen, D. 2012. Co-infection with Cucumber vein yellowing virus and Cucurbit yellow stunting disorder virus leading to synergism in cucumber. Plant Pathol. 61:468-478.

Gómez, P., Sempere, R., Aranda, M., and Elena, S. 2012b. Phylodynamics of Pepino mosaic virus in Spain. Eur. J. Plant Pathol. 134:445-449.

Gómez, P., Sempere, R., and Aranda, M. A. 2012a. Pepino mosaic virus and Tomato torrado virus: Two emerging viruses affecting tomato crops in the Mediterranean Basin. Pages 505-532 in: Viruses and Virus Diseases of Vegetables in the Mediterranean Basin, Advances in Virus Research. G. Loebenstein and H. Lecoq, eds. Academic Press, San Diego, CA.

Gómez, P., Sempere, R. N., Amari, K., Gómez-Aix, C., and Aranda, M. A. 2010. Epidemics of Tomato torrado virus, Pepino mosaic virus and Tomato chlorosis virus in tomato crops: Do mixed infections contribute to torrado disease epidemiology? Ann. Appl. Biol. 156:401-410.

Gómez, P., Sempere, R. N., Elena, S. F., and Aranda, M. A. 2009. Mixed infections of Pepino mosaic virus strains modulate the evolutionary dynamics of this emergent virus. J. Virol. 83:12378-12387.

Gómez-Aix, C., Alcaide, C., Agüero, J., Faize, M., Juárez, M., Díaz-Marrero, C. J., et al. 2019. Genetic diversity and population structure of Pepino mosaic virus in tomato crops of Spain and Morocco. Ann. Appl. Biol. 174: 284-292.

Gonzalez-Jara, P., Fraile, A., Canto, T., and Garcia-Arenal, F. 2009. The multiplicity of infection of a plant virus varies during colonization of its eukaryotic host. J. Virol. 83:7487-7494.

Gutiérrez, S., Pirolles, E., Yvon, M., Baecker, V., Michalakis, Y., and Blanc, S. 2015. The multiplicity of cellular infection changes depending on the route of cell infection in a plant virus. J. Virol. 89:9665-9675.
Hanssen, I. M., Lapidot, M., and Thomma, B. 2010. Emerging viral diseases of tomato crops. Mol. Plant-Microbe Interact. 23:539-548.

Hanssen, I. M., and Thomma, B. P. H. J. 2010. Pepino mosaic virus: A successful pathogen that rapidly evolved from emerging to endemic in tomato crops. Mol. Plant Pathol. 11:179-189.

Juarez, M., Legua, P., Mengual, C. M., Kassem, M. A., Sempere, R. N., Gómez, P., et al. 2013. Relative incidence, spatial distribution and genetic diversity of cucurbit viruses in eastern Spain. Ann. Appl. Biol. 162: 362-370.

Kassem, M., Juárez, M., Gómez, P., Mengual, C., Sempere, R., Plaza, M., et al. 2013. Genetic diversity and potential vectors and reservoirs of Cucurbit aphid-borne yellows virus in southeastern Spain. Phytopathology 103: 1188-1197.

Komatsu, K., Yamaji, Y., Ozeki, J., Hashimoto, M., Kagiwada, S., Takahashi, S., et al. 2008. Nucleotide sequence analysis of seven Japanese isolates of Plantago asiatica mosaic virus (PlAMV): A unique potexvirus with significantly high genomic and biological variability within the species. Arch. Virol. 153:193-198.

Kumar, S., Stecher, G., and Tamura, K. 2016. MEGA7: Molecular Evolutionary Genetics Analysis version 7.0 for bigger datasets. Mol. Biol. Evol. 33:1870-1874.

Lafforgue, G., Sardanyés, J., and Elena, S. 2011. Differences in accumulation and virulence determine the outcome of competition during Tobacco etch virus coinfection. PLoS One 6:e17917.

Lalić, J., Cuevas, J. M., and Elena, S. F. 2011. Effect of host species on the distribution of mutational fitness effects for an RNA virus. PLoS Genet. 7: e1002378

Laufer, M., Mohammad, H., Christ, D. S., Riedel, D., Maiss, E., Varrelmann, M., et al. 2018. Fluorescent labelling of Beet necrotic yellow vein virus and Beet soil-borne mosaic virus for co-and superinfection experiments in $\mathrm{Ni}$ cotiana benthamiana. J. Gen. Virol. 99:1321-1330.

Leeks, A., Segredo-Otero, E. A., Sanjuán, R., and West, S. A. 2018. Beneficial coinfection can promote within-host viral diversity. Virus Evol. 4:vey028.

Lim, H. S., Vaira, A. M., Reinsel, M. D., Bae, H., Bailey, B. A., Dornier, L. L., et al. 2010. Pathogenicity of Alternanthera mosaic virus is affected by determinants in RNA-dependent RNA polymerase and by reduced efficacy of silencing suppression in a movement-competent TGB1. J. Gen. Virol. 91:277-287.

McLeish, M., Sacristán, S., Fraile, A., and García-Arenal, F. 2019. Coinfection organizes epidemiological networks of viruses and hosts and reveals hubs of transmission. Phytopathology 109:1003-1010.

Montville, R., Froissart, R., Remold, S. K., Tenaillon, O., and Turner, P. E. 2005. Evolution of mutational robustness in an RNA virus. PLoS Biol. 3:e381.

Moreno-Pérez, M. G., García-Luque, I., Fraile, A., and García-Arenal, F. 2016. Mutations that determine resistance breaking in a plant RNA virus have pleiotropic effects on its fitness that depend on the host environment and on the type, single or mixed, of infection. J. Virol. 90:9128-9137.

Moreno-Pérez, M. G., Pagán, I., Aragón-Caballero, L., Cáceres, F., Fraile, A., and García-Arenal, F. 2014. Ecological and genetic determinants of Pepino mosaic virus emergence. J. Virol. 88:3359-3368.

Moriones, E., and Navas-Castillo, J. 2008. Rapid evolution of the population of begomoviruses associated with the tomato yellow leaf curl disease after invasion of a new ecological niche. Span. J. Agric. Res.: 147-159.

Morozov, S. Y., and Solovyev, A. G. 2003. Triple gene block: Modular design of a multifunctional machine for plant virus movement. J. Gen. Virol. 84: $1351-1366$.

Navas-Castillo, J., Camero, R., Bueno, M., and Moriones, E. 2000. Severe yellowing outbreaks in tomato in Spain associated with infections of Tomato chlorosis virus. Plant Dis. 84:835-837.

Nee, S. 2016. The evolutionary ecology of molecular replicators. R. Soc. Open Sci. 3:160235

Ojosnegros, S., Beerenwinkel, N., Antal, T., Nowak, M. A., Escarmís, C., and Domingo, E. 2010. Competition-colonization dynamics in an RNA virus. Proc. Natl. Acad. Sci. 107:2108-2112.

Pagán, I. 2018. The diversity, evolution and epidemiology of plant viruses: A phylogenetic view. Infect. Genet. Evol. 65:187-199.

Pagán, I., del Carmen Córdoba-Sellés, M., Martínez-Priego, L., Fraile, A., Malpica, J. M., Jordá, C., et al. 2006. Genetic structure of the population of Pepino mosaic virus infecting tomato crops in Spain. Phytopathology 96: 274-279.

Pagán, I., and García-Arenal, F. 2018. Population genomics of plant viruses. Pages 233-265 in: Population Genomics: Microorganisms. Springer, Cham, Switzerland.

Pallás, V., Más, P., and Sánchez-Navarro, J. A. 1998. Detection of plant RNA viruses by nonisotopic dot-blot hybridization. Pages 461-468 in: Plant Virology Protocols: From Virus Isolation to Transgenic Resistance. G. D. Foster and S. C. Taylor, eds. Humana Press, Totowa, NJ.

Poirier, E. Z., and Vignuzzi, M. 2017. Virus population dynamics during infection. Curr. Opin. Virol. 23:82-87. 
Roossinck, M. J. 2012. Plant virus metagenomics: Biodiversity and ecology. Annu. Rev. Genet. 46:359-369.

Rozas, J., Ferrer-Mata, A., Sanchez-DelBarrio, J. C., Guirao-Rico, S., Librado, P., Ramos-Onsins, S. E., et al. 2017. DnaSP 6: DNA sequence polymorphism analysis of large data sets. Mol. Biol. Evol. 34:3299-3302.

Rubio, L., Ayllon, M. A., Kong, P., Fernandez, A., Polek, M., Guerri, J., et al. 2001. Genetic variation of Citrus tristeza virus isolates from California and Spain: Evidence for mixed infections and recombination. J. Virol. 75: 8054-8062.

Sempere, R. N., Gómez, P., Truniger, V., and Aranda, M. A. 2011. Development of expression vectors based on pepino mosaic virus. Plant Methods 7:6.

Solovyev, A. G., Kalinina, N. O., and Morozov, S. Y. 2012. Recent advances in research of plant virus movement mediated by triple gene block. Front. Plant Sci. 3:276.

Syller, J. 2012. Facilitative and antagonistic interactions between plant viruses in mixed infections. Mol. Plant Pathol. 13:204-216.

Syller, J., and Grupa, A. 2016. Antagonistic within-host interactions between plant viruses: Molecular basis and impact on viral and host fitness. Mol. Plant Pathol. 17:769-782.

Taiwo, M. A., Kareem, K. T., Nsa, I. Y., and Hughes, J. D. A. 2007. Cowpea viruses: Effect of single and mixed infections on symptomatology and virus concentration. Virol. J. 4:95.
Tilsner, J., Linnik, O., Louveaux, M., Roberts, I. M., Chapman, S. N., and Oparka, K. J. 2013. Replication and trafficking of a plant virus are coupled at the entrances of plasmodesmata. J. Cell Biol. 201:981-995.

Tollenaere, C., Susi, H., and Laine, A. L. 2016. Evolutionary and epidemiological implications of multiple infection in plants. Trends Plant Sci. 21: 80-90.

Tuomivirta, T. T., and Hantula, J. 2005. Three unrelated viruses occur in a single isolate of Gremmeniella abietina var. abietina type A. Virus Res. 110:31-39.

van der Vlugt, R. A. A., Stijger, C. C. M. M., Verhoeven, J. T. J., and Lesemann, D. E. 2000. First report of Pepino mosaic virus on tomato. Plant Dis. 84:103.

Vignuzzi, M., Stone, J. K., Arnold, J. J., Cameron, C. E., and Andino, R. 2006. Quasispecies diversity determines pathogenesis through cooperative interactions in a viral population. Nature 439:344-348.

Werkman, A. W., and Sansford, C. 2010. Pest risk analysis for Pepino mosaic virus for the EU. Deliverable Report 4.3. European Union Sixth Framework Pepeira Research Project.

Zhang, H., Tan, X., He, Y., Xie, K., Li, L., Wang, R., et al. 2019. Rice blackstreaked dwarf virus $\mathrm{P} 10$ acts as either a synergistic or an antagonistic determinant during superinfection with related or unrelated virus. Mol. Plant Pathol. 20:641-655. 